ISSN 0258-7122

Bangladesh J. Agril. Res. 36(3) : 407-413, September 2011

\title{
EFFECT OF NPK ON THE INCIDENCE OF ALTERNARIA LEAF BLIGHT OF MUSTARD
}

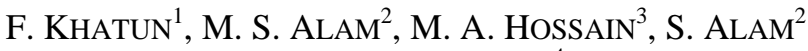 \\ AND P. K. MALAKER ${ }^{4}$
}

\begin{abstract}
A 2-year field study was carried out to find out the effect of three macro nutrients NPK on the severity of Alternaria leaf blight and yield of mustard. Nitrogen@80,100,120,140, and 160, phosphorus@ 15, 30, and 45, and potassium @ 30,60, and 90 kg/ha were applied. Among the nutrients, 120-30$60 \mathrm{~kg} \mathrm{NPK/ha}$ was considered as recommended dose on the basis of soil test. Fertilizer dose 120-30-90 kg/ha appeared to be the best combination of N, P, and $\mathrm{K}$ in reducing the disease incidence and to increase seed yield of mustard. Higher dose of K (90 kg/ha) decreased the incidence of Alternaria leaf blight but higher dose of nitrogen (140 and $160 \mathrm{~kg} \mathrm{~N} / \mathrm{ha}$ ) increased the disease incidence. The highest seed yield of $1718 \mathrm{~kg} / \mathrm{ha}$ was obtained with $120-30-90 \mathrm{~kg}$ of NPK/ha which was statistically similar to the doses of 120-30-60 and 120-45$60 \mathrm{~kg}$ of NPK/ha. Higher seed yield and lower disease severity was also observed under these three treatments as compared to other treatments.
\end{abstract}

Keywords: Mustard, Alternaria leaf blight, nutrient management.

\section{Introduction}

Mustard (Brassica juncea, B.campestris and B.napus) is one of the important oilseed crops in Bangladesh. The average yield of mustard in Bangladesh is $1001 \mathrm{~kg} / \mathrm{ha}$ (BBS, 2008), which is low compared to many mustard growing countries of the world (Ahmed et al., 1988). The crop suffers from 14 diseases in Bangladesh (Bakr et al., 2007; Meah, 1986) where Alternaria blight is the most serious and widely distributed in the country (Kaul and Das, 1986). The disease causes blight of leaf, pod and stem (Ahmed and Ahmed, 1994) and seed abnormalities (Howlider et al., 1991). The disease is caused by A. brassicae and A. brassicicola. It is endemic in Bangladesh and most of the cultivated varieties are susceptible to this disease. The disease causes yield losses of 40$70 \%$ in India (Vishwanath and Kolte, 1997) and 30-60\% in Bangladesh (Ahmed and Ahmed, 1994). In addition to direct yield losses, the disease adversely affects the seed quality by reducing seed size, seed discolouration and reduction in oil contents (Howlider et al., 1991). Application of N, P, and $\mathrm{K}$ alone or in combination increases seed yield and oil content of mustard

\footnotetext{
${ }^{1}$ Senior Scientific Officer, Regional Agricultural Research Station, Jessore, ${ }^{2 \& 4}$ Professor, Dept. of Botany, Rajshahi University (RU), Rajshahi and ${ }^{3}$ Senior Scientific Officer, Pulses Research Centre, BARI, Gazipur, ${ }^{5}$ Principal Scientific Officer, WRC, Dianajpur, Bangladesh.
} 
(Singh, 2002). Application of balanced fertilizers is very important for the management of many diseases. Severity of Alternaria blight of many crops can be reduced by applying nutrients at suitable doses (Singh et al., 1992). Jessore is one of the major mustard growing areas in Bangladesh, but the farmers usually grow local varieties with their own fertilizer management. So, the yield is very low. There is a good scope to introduce high yielding variety of mustard with optimum fertilizer management in that area which will help to minimize the yield and gap between existing production and potential yield of the crop. Therefore, the experiment was carried out to determine the optimum N, P, and $\mathrm{K}$ combination for the management of Alternaria blight of high yielding mustard variety BARI Sarisha-6.

\section{Materials and Method}

The experiment was conducted in the calcareous soil of Regional Agricultural Research Station (RARS), BARI, Jessore during the rabi season of 2004-05 and 2005-06. The land belongs to High Ganges River Floodplain agro-ecological zone and Gopalpur soil series having high $\mathrm{pH}$ value (8.1) with low organic matter $(1.32 \%)$. Among the three macro elements, nitrogen $(\mathrm{N})$ was applied at the rate of $80,100,120,140$, and $160 \mathrm{~kg} / \mathrm{ha}$, phosphorus (P) at 15, 30, and $45 \mathrm{~kg} / \mathrm{ha}$ and potassium (K) at 30,60 , and $90 \mathrm{~kg} / \mathrm{ha}$. The nutrient elements were applied in 10 different treatments combination viz. $T_{1}=80-30-60, T_{2}=100-30-60, T_{3}=120$ 30-60, $\mathrm{T}_{4}=140-30-60, \mathrm{~T}_{5}=160-30-60, \mathrm{~T}_{6}=120-15-60, \mathrm{~T}_{7}=120-45-60, \mathrm{~T}_{8}=$ 120-30-30, $\mathrm{T}_{9}=120-30-90 \mathrm{~kg} / \mathrm{ha}$, and Tip (control). Urea, triple super phosphate, and muriate of potash were used as sources of N, P, and K. Among the treatments, $T_{3}$ was considered as standard check (BARC, 2005). The treatment $\mathrm{T}_{10}$ received no nutrient and used as control. Recommended doses of $\mathrm{S}, \mathrm{Zn}$, and B were applied at the rate of 30-2-1 kg/ha (BARC, 2005). The experiment was laid out in a randomized complete block design with three replications. The unit plot size was $4 \mathrm{~m} \times 3 \mathrm{~m}$. This layout was kept undisturbed for the second year of the study. Each year, mustard variety BARI Sarisha- 6 was sown on $1^{\text {st }}$ week of November maintaining a spacing of $30 \mathrm{~cm}$ between the lines. Intercultural operation viz., weeding, irrigation, and insecticide spray were done as and when required. Data on percent infected leaf, leaf area diseased, infected siliqua, and number of spots/siliqua, yield and some yield contributing characters were recorded. The data were analyzed statistically for ANOVA and differences in means were evaluated for significance by Duncan's Multiple Range Test (DMRT).

\section{Results and Discussion}

\section{Percentage of infected leaf and leaf area diseased}

Application of N-P-K at nine different combinations significantly reduced percent infected leaves over control in both the years except 120-30-30 in 2005- 
$06 \mathrm{~kg} / \mathrm{ha}$. The lowest percentage of infected leaves was obtained with 80-30-60 $\mathrm{kg} / \mathrm{ha}$ followed by $100-30-60,120-45-60$, and $120-3060 \mathrm{~kg} / \mathrm{ha}$ in both the years. Effectiveness of the four treatments was not significantly different. In 2004-05, significant reduction in percent leaf area diseased was obtained with N-P-K at 120-30-90, 120-30-60 and 80-30-60, kg/ha compared to control (0-0-0). The effectiveness of three doses was statistically similar. In 2005-06, only the 120$30-90 \mathrm{~kg} / \mathrm{ha}$ of N-P-K gave significant reduction of the disease over control (Table 1).

Table 1. Effect of NPK leaf infection and siliqua infection of mustard.

\begin{tabular}{|c|c|c|c|c|c|c|c|c|}
\hline \multirow{2}{*}{$\begin{array}{c}\text { Dose of } \\
\text { NPK } \\
(\mathrm{kg} / \mathrm{ha})\end{array}$} & \multicolumn{2}{|c|}{$\%$ Infected leaf } & \multicolumn{2}{|c|}{$\begin{array}{c}\text { \% Leaf area } \\
\text { diseased }\end{array}$} & \multicolumn{2}{|c|}{ \% Infected siliqua } & \multicolumn{2}{|c|}{ Spots siliqua (no.) } \\
\hline & 2004-05 & 2005-06 & 2004-05 & 2005-06 & 2004-05 & 2005-06 & 2004-05 & 2005-06 \\
\hline$-30-60$ & 28.64d & $30.64 d$ & $14.58 \mathrm{c}$ & $17.48 \mathrm{bc}$ & $16.89 d$ & $18.54 \mathrm{f}$ & 9.104 & $10.13 f$ \\
\hline $00-30-60$ & 29.90cd & $33.65 c d$ & $15.13 \mathrm{bc}$ & 18.61abc & 17.99cd & 20.33ef & $11.20 \mathrm{c}$ & $12.00 \mathrm{e}$ \\
\hline $20-30-60$ & 31.79bcd & $36.24 \mathrm{~cd}$ & $14.54 \mathrm{c}$ & 18.83abc & $19.12 \mathrm{c}$ & 22.01 cde & $12.09 \mathrm{c}$ & $13.13 d$ \\
\hline $40-30-60$ & $33.93 b$ & $38.80 \mathrm{bc}$ & 16.73abc & $20.77 a$ & $22.27 b$ & $25.13 b c$ & $14.30 \mathrm{~b}$ & $15.62 b c$ \\
\hline $60-30-60$ & $34.22 b$ & 39.34bc & $19.83 a$ & $21.04 \mathrm{a}$ & $25.49 a$ & $28.49 a$ & $16.02 \mathrm{a}$ & $16.67 \mathrm{ab}$ \\
\hline $120-15-60$ & $32.50 \mathrm{bc}$ & 39.77bc & 18.24ab & 18.96abc & 19.31c & 23.04cde & $11.79 \mathrm{c}$ & $14.03 \mathrm{~cd}$ \\
\hline $20-$ & 31. & 35. & 15.1 & 17 & 18 & 21 & c & 13 \\
\hline $120-30-30$ & 33.12bc & 42.86ab & $18.68 \mathrm{a}$ & $20.53 a$ & $24.69 a$ & 27.39ab & $16.89 a$ & $18.04 \mathrm{a}$ \\
\hline $20-30-90$ & 29.75cd & 37.53bc & $14.42 \mathrm{c}$ & $16.53 c$ & $18.89 \mathrm{c}$ & 23.82cd & $8.90 \mathrm{~d}$ & $10.32 \mathrm{f}$ \\
\hline $0-0-0$ & 37.39a & $48.29 a$ & $18.21 \mathrm{ab}$ & 19.03ab & 25.13a & 27.38ab & $16.32 \mathrm{a}$ & $18.34 \mathrm{a}$ \\
\hline
\end{tabular}

Means within a column followed by same letter(s) are not significantly different at 5\% level of probability by DMRT.

\section{Percentage of infected siliqua and spot number per siliqua}

In both 2004-05 and 2005-06 crop seasons, the percentage of infected siliqua was significantly reduced due to application of N-P-K at all doses compared to control (0-0-0) except the two doses, $160-30-60$ and 120-30-30 kg/ha. The lowest percentage of infected siliqua was achieved with the dose 80-30-60 kg/ha, which was statistically similar to $100-30-60 \mathrm{~kg} / \mathrm{ha}$. The third lowest percentage of infected siliqua was observed at $120-45-60 \mathrm{~kg} / \mathrm{ha}$, which was statistically similar to $120-30-60,120-15-60$, and $120-30-90 \mathrm{~kg} / \mathrm{ha}$. Like percentage of infected siliqua, except 160-30-60 and 120-30-30 kg/ha, all other doses of N-P-K caused significant reduction in spot number/siliqua compared to control. The lowest percentage of infected siliqua was achieved with the dose $80-30-60 \mathrm{~kg} / \mathrm{ha}$, which was statistically similar to $100-30-90 \mathrm{~kg} / \mathrm{ha}$. Differences in spot number recorded at 120-30-60, 120-15-60 and 120-45-60 kg/ha were significant (Table 1). 


\section{Plant growth and yield contributing parameters}

In both the seasons of experiment, plant height, siliqua number/plant, seed number/siliqua, and 1000-seed weight increased remarkably due to application of N-P-K at different doses tested compared to control. The maximum plant height and number of siliqua/plant were achieved with 120-30-90 kg/ha. Its effect on this parameter was statistically Similar to 120-45-60, 160-30-30, 14030-60 and 120-30-60. The highest number of seeds/siliqua as well as 1000-seed weight was recorded from the dose $120-45-60 \mathrm{~kg} / \mathrm{ha}$, which was statically similar to $120-30$ 90, 160-30-60, 140-30-60 and 120-30-60 kg/ha (Table 2).

Table 2. Effect of NPK on the plant growth and some yield contributing characters of mustard.

\begin{tabular}{|c|c|c|c|c|c|c|c|c|}
\hline \multirow{2}{*}{$\begin{array}{c}\text { Dose of } \\
\text { NPK } \\
\text { (kg/ha) }\end{array}$} & \multicolumn{2}{|c|}{ Plant height (cm) } & \multicolumn{2}{|c|}{ Siliqua/plant (no.) } & \multicolumn{2}{|c|}{ Seeds/siliqua (no.) } & \multicolumn{2}{|c|}{ 1000-seed wt (g) } \\
\hline & 2004-05 & 2005-06 & 2004-05 & 2005-06 & 2004-05 & 2005-06 & 2004-05 & 2005-06 \\
\hline $80-30-60$ & 133. & c & 88.3de & 79.3 & $21.3 \mathrm{~cd}$ & $19.9 \mathrm{f}$ & 3.09cd & 3.03cd \\
\hline $0-60$ & 141 & 3bc & 96.7cd & 8 & 22. & 21. & 3.2 & $\mathrm{~cd}$ \\
\hline $120-30-60$ & $148.2 \mathrm{a}$ & 141.7ab & 109.0ab & 103.6ab & 23.9ab & 22.9ab & $3.37 \mathrm{ab}$ & $3.26 \mathrm{ab}$ \\
\hline $140-30-60$ & 149.0a & 142.3ab & 108.3ab & 101.5ab & $23.2 \mathrm{ab}$ & 21.9bcd & $3.35 \mathrm{ab}$ & 3.21ab \\
\hline $160-30-60$ & 150. & 14 & 106.0a6c & 98.7 & 22.93abc & 21. & 3.30 & 3.19abc \\
\hline $120-15-60$ & $131.6 b$ & $122.9 c$ & 82.3e & 74.3e & 20.9de & $19.8 \mathrm{f}$ & 3.16bcd & $3.02 \mathrm{~cd}$ \\
\hline $120-45-60$ & 147.9a & 139.8ab & $115.7 a$ & 109.3a & $24.3 a$ & $23.2 \mathrm{a}$ & $3.41 \mathrm{a}$ & 3.33a \\
\hline $120-30-30$ & 140.4ab & 131.6bc & $100.7 b c$ & $95.9 \mathrm{bc}$ & 22.3bcd & $20.9 \mathrm{e}$ & 3.23abc & $3.11 \mathrm{bcd}$ \\
\hline $120-30-90$ & $152.6 a$ & $147.7 \mathrm{a}$ & $114.7 \mathrm{a}$ & 107.8a & $24.1 \mathrm{a}$ & $22.7 \mathrm{ab}$ & 3.36ab & 3.23ab \\
\hline $0-0-0$ & $89.2 \mathrm{c}$ & $78.1 \mathrm{~d}$ & $52.0 \mathrm{f}$ & $45.8 \mathrm{f}$ & $19.60 \mathrm{e}$ & $17.3 \mathrm{~g}$ & $3.00 \mathrm{~d}$ & $2.98 \mathrm{~d}$ \\
\hline
\end{tabular}

Means within a column followed by same letter(s) are not significantly different at 5\% level of probability by DMRT.

\section{Seed yield}

The highest seed yield was achieved with N-P-K at 120-30-90 kg/ha, followed by $120-45-60,12030-60$, and 140-30-60 kg/ha. The lowest yield increase' was observed at $80-30-60 \mathrm{~kg} / \mathrm{ha}$ followed by 120-15-60, 100-30-60, 120-30-30, and $160-30-60 \mathrm{~kg} / \mathrm{ha}$. The seed yield was lower at $160 \mathrm{~kg}, \mathrm{~N} / \mathrm{ha}$ compared to $120 \mathrm{~kg}$ $\mathrm{N} / \mathrm{ha}$. Higher dose of P (45 kg/ha) and $\mathrm{K}(90 \mathrm{~kg} / \mathrm{ha})$ showed no appreciable effect on seed yield. Again lower dose of P (15 kg/ha) and K (30 kg/ha) produced 1098 and $1315 \mathrm{~kg}$ seed yield/ha, respectively (Fig. 1). Such results indicate the positive influence of $\mathrm{P}$ and $\mathrm{K}$ on mustard yield when applied along with $\times$ blanket dose of 120-30-2-1 kg N-S-Zn-B/ha. 


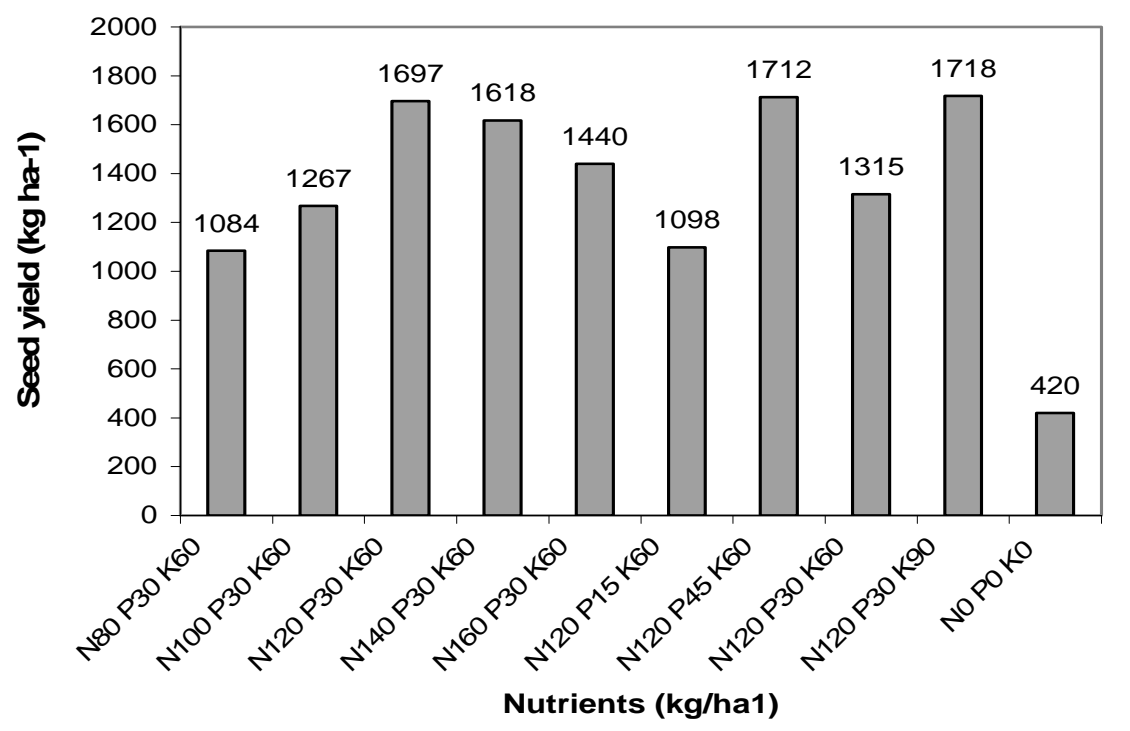

Fig 1. Effect of different doses of NPK on seed yield of mustard (mean of two years).

Results of the present investigation indicated that $\mathrm{N}$ fertilizer plays an important role on disease development and seed yield of mustard. At lower dose of $\mathrm{N}$, disease incidence remained low but seed yield reduced drastically. With increase in level of $\mathrm{N}$, the incidence of disease and seed yield was also increased up to $120 \mathrm{~kg} \mathrm{~N} / \mathrm{ha}$. It appeared that seed yield of mustard reduced and disease incidence increased at higher doses of $\mathrm{N}$ (140 and $160 \mathrm{~kg} / \mathrm{ha}$ ). This might be due to increase in proneness plants to the disease at higher dose of N. Successive increase of $\mathrm{N}$ at $20 \mathrm{~kg} / \mathrm{ha}$ over optimum dose of $120 \mathrm{~kg}$ under constant level of $\mathrm{P}$ and $\mathrm{K}$ gave $79 \mathrm{~kg}$ (at $140 \mathrm{~kg} \mathrm{~N} / \mathrm{ha}$ ) and $257 \mathrm{~kg} / \mathrm{ha}$ (at $160 \mathrm{~kg} \mathrm{~N} / \mathrm{ha}$ ) lower seed yield.

Potassium had depressive effect on diseases incidence. Higher dose of K (90 $\mathrm{kg} / \mathrm{ha}$ ) decreased the incidence of Alternaria leaf blight and increased seed yield of mustard but not significantly over the recommended dose ( $60 \mathrm{~kg} / \mathrm{ha})$. The best dose of $\mathrm{N}$ minimizing disease incidence and increased seed yield was $120 \mathrm{~kg} / \mathrm{ha}$. Higher dose of N (140 and $160 \mathrm{~kg} / \mathrm{ha}$ ) and lower dose of $\mathrm{K}(30 \mathrm{~kg} / \mathrm{ha})$ increased number of spots/siliqua compared to other treatments. The highest dose of P (45 $\mathrm{kg} / \mathrm{ha}^{-1}$ ) gave the highest number of seeds/siliqua and 1000-seed weight.

Several reports indicate that soil application of NPK decreased Alternaria leaf blight intensity to various levels and increased seed yield of mustard. Higher dose of $\mathrm{N}$ than a balanced rate enhanced the severity and incidence of various 
diseases caused by Alternaria brassicicola, A. brassicae, A. porri, A. solani, and Alternaria spp. (Ferdous, 1990; Dasgupta et al., 1991). Singh et al. (1992) reported that $\mathrm{P}$ has no significant effect on severity of Alternaria but severity of leaf spot increased with the increase of $\mathrm{N}$, while addition of $\mathrm{K}$ decreased disease severity. Singh (2002) also reported that $120 \mathrm{~kg} \mathrm{~N} / \mathrm{ha}$ and $45 \mathrm{~kg} \mathrm{P} / \mathrm{ha}$ significantly increased the seed and yield attributes of mustard. Singh et al. (2003) observed that the $\mathrm{N}$ level higher than $120 \mathrm{~kg} / \mathrm{ha}$ did not significantly increase the yield and yield attributes.

The plants take up the nutrient from fertilizers and utilize them in the plant metabolic system for strengthening the defence mechanism of plant through formation of different kinds of barriers (both mechanical and biochemical), which ultimately opposes the infection by plant pathogenic organisms (Bradford, 1975; Hossain and Mian, 2004). In the present study, the treatment $T_{3}$ having 120-30-60 kg NPK/ha with a blanket dose of 30-2-1 kg SZnB/ha was found to be the most effective nutrient combination to reduce Alternaria blight and increase seed yield of mustard.

\section{Conclusion}

Based on findings of the present investigation, it may be concluded that potassium decreases the incidence of Alternaria leaf blight and the seed yield increases with the increase in level of $\mathrm{N}$ upto $120 \mathrm{~kg} / \mathrm{ha}$. If the level of $\mathrm{N}$ is increased above $120 \mathrm{~kg} / \mathrm{ha}$ it reduces the seed yield and increase disease incidence. The NPK dose of 120-30-60 kg/ha with a blanket dose of 30-2-1 kg $\mathrm{SZnB} / \mathrm{ha}$ is the most effective to reduce Alternaria blight and increase seed yield of mustard.

\section{References}

Ahmed, M.S., M. Elias. and J. Ahmed. 1988. Results of farm level socio-economic study on mustard production. Bangladesh J. Agril. Res. 13(1): 20-23.

Ahmed, M.U. and H.U. Ahmed. 1994. Disease Management, Recommendation and Future Plan of Oilseeds Crop in Bangladesh. In Proc. workshop on transfer of technology of CDP crops under Research-Extension Linkage programme. pp. 46-56.

Bakr, M.A., H.U. Ahmed and M.A.W. Mian. (eds). 2007. Proceedings of the national workshop on "Strategic Intervention on Plant Pathological Research" in Bangladesh, 11-12 February 2007, BARI, Joydebpur, Gazipur. 344 p.

BARC. 2005. Fertilizer Recommendation Guide-2005. BARC Pub. No. 45. Bangladesh Agricultural Research Council, Dhaka.

BBS. 2008. Year Book of Agricultural Statistics of Bangladesh, Bangladesh Bureau of Statistics, Ministry of Planning. Govt. of the People's Republic of Bangladesh. Dhaka. 
Bradford, G.R. 1975. Diagnostic criteria for plant and soils. Edited by Homer D. Chapman. First Indian Print. Eurasia Publishing House (P) Ltd. Ramnagar, New Delhi-110055, pp. 34-35 and 38.

Dasgupta, B., P.K. Ghosh. and B.N.Chatterjee. 1991. Effect of different dates and levels of nitrogen fertilizers on Alternaria blight disease and productivity of Indian mustard (Brassica juncea L.) Czern and Coss. Environment and Ecology 9(l): 118-123.

Ferdous, S.M. 1990. Effect of fertilizers, organic amendments and plant crude extracts on the incidence of Alternaria blight of mustard. M.Sc. Ag Thesis. Dept. of Plant Pathology, BAU, Mymensingh. 33 p.

Hossain, M.S. and I.H. Mian. 2004. Effect of foliar fungicides on the control of Alternaria blight of cabbage seed crops. Bangladesh J. Plant Pathol. 20(1\&2): 43-48.

Howlider, M.A.R., M.B. Meah., M.Jalaluddin. and M.A. Rahman. 1991. Effect of fungicides on Alternaria blight, yield and seed quality of mustard. Bangladesh $J$. Agric. Sci. 18(1): 127-132.

Kaul, A.K. and M.L. Das. 1986. Oilseeds in Bangladesh, BARI, Joydebpur, Gazipur, pp. 42-62.

Meah, M.B. 1986. Management of diseases of oilseeds: Mustard, groundnut and sesame. In Proc. "BAU Research Program" workshop held on 4-5 October, 1 ?86. No. 1: 82100.

Singh, B.P., S.P.Singh., A. Mohammad and P.P. Sinha. 1992. Effect of nitrogen, phosphorus and potassium on the development of Alternaria leaf spot of cabbage. Indian Phytopath. 45(2): 245-248.

Singh, G.K., P. Kedar. and K. Prasad. 2003. Effect of row spacing, nitrogen levels and basis of $\mathrm{N}$ application on yield attributes and yield of mustard variety Basanti. Crop Res. Hisar. 25(3): 427-430.

Singh, P.C. 2002. Effect of different levels of nitrogen and phosphorus on yield, yield components and oil content of mustard (Brassica juncea) cv. Varuna. J. Living World. 9(1): 1-4.

Vishwanath, K. and S.J. Kolte. 1997. Variability in Alternaria brassicae: Response to host genotypes, toxin production and fungicides. Indian Phytopath. 50(3): 373-381. 